\title{
ANALISIS SWOT DALAM PENGEMBANGAN DESA WISATA \\ PULESARI KECAMATAN TURI KABUPATEN SLEMAN
}

\author{
Suwarjo \\ Program Studi Ilmu Administrasi Publik, Universitas Widya Mataram \\ jojoaufa@gmail.com
}

\begin{abstract}
Abstraksi
Penelitian ini bertujuan untuk melakukan studi SWOT dalam pengembangan Desa Wisata Pulesari Kecamatan Turi Kabupaten Sleman. Pendekatan deskriptif kualitatif digunakan untuk mendapatkan gambaran yang lengkap tentang Desa Wisata Pulesari. Data penelitian primer dan sekunder diperoleh melalui wawancara, dokumentasi, observasi dan FGD.

Hasil penelitian menunjukkan bahwa pengembangan Desa Wisata Pulesari berbasis SWOT sangat dibutuhkan. Hasil studi SWOT yang dilakukan dapat memberikan arahan strategis yang tepat dalam pengembangan Desa Wisata Pulesari. Beberapa strategi unggulan yang ditawarkan: (1) upaya peningkatan nilai ekonomi salak dengan memberikan pelatihan mengolah buah salak menjadi berbagai makanan dan minuman, pengemasan dan pemasarannya; (2) menghadirkan tradisi lokal secara periodik sebagai daya tarik wisata; (3) meningkatkan jumlah homestay dan meningkatkan standar kelayakan mereka sebagai objek wisata; (4) Mengembangkan ikon wisata khas yang berbeda dari desa wisata lainnya dengan pilihan ikon khas "Desa Wisata Pulesari: desa wisata budaya dan outbond river tracking"; dan (5) membangun jejaring dengan instansi pemerintah dan swasta untuk mendapatkan pendampingan, pelatihan dan pendampingan dalam pengadaan dan peningkatan sarana penunjang wisata serta peningkatan akses jalan akses desa wisata.

Menindaklanjuti tawaran sejumlah strategi tersebut, Pengelola Desa Wisata Pulesari perlu: 1) melakukan kajian lebih lanjut terhadap strategi yang telah ditawarkan melalui forum bersama pengelola desa wisata untuk menentukan skala prioritas dari strategi yang dipilih. 2) merumuskan langkah-langkah koordinasi dan menjalin komunikasi yang intens dengan berbagai pihak, baik dengan Pemerintah Desa Wonokerto, Pemerintah Kabupaten Sleman melalui Dinas Pariwisata, pihak lain seperti perusahaan untuk mendapatkan dukungan anggaran serta pelatihan, pendampingan dan fasilitasi untuk pembangunan Desa Wisata Pulesari.
\end{abstract}

Kata Kunci: Desa Wisata, SWOT

\footnotetext{
Abstract

This study aims to conduct a SWOT study in the development of Pulesari Tourism Village, Turi District, Sleman Regency. A qualitative descriptive approach is used to get a
} 
complete picture of Pulesari Tourism Village. Primary and secondary research data obtained through interviews, documentation, observation and FGD.

The results showed that the development of Pulesari Tourism Village based on SWOT was very much needed. The results of the SWOT study conducted can provide the right strategic direction in the development of the Pulesari Tourism Village. Some of the superior strategies offered: (1) efforts to increase the economic value of zalacca by providing training to process zalacca fruits into various foods and drinks, packaging and marketing them; (2) presenting periodic local traditions as a tourist attraction; (3) increase the number of homestays and increase their eligibility standards as a tourist attraction; (4) Developing distinctive tourism icons that are different from other tourist villages with a choice of distinctive icons "Pulesari Tourism Village: cultural tourism village and outbound river tracking"; and (5) building networks with government agencies and the private sector to get assistance, training and assistance in the procurement and improvement of tourist support facilities as well as improving access to tourist village access roads.

Following up on the offer of a number of these strategies, the Pulesari Tourism Village Manager needs to: 1) conduct further studies of the strategies that have been offered through a forum with the tourism village manager to determine the priority scale of the strategy chosen. 2) formulate coordination steps and establish intense communication with various parties, both with the Wonokerto Village Government, Sleman Regency Government through the Department of Tourism, other parties such as companies to obtain budget support as well as training, assistance and facilitation for the development of Pulesari Tourism Village.

Keywords: tourist village; SWOT

\section{Pendahuluan}

Indonesia memiliki potensi yang besar untuk menghasilkan devisa dari sektor pariwisata. Pariwisata adalah salah satu dari industri gaya baru, yang mampu menyediakan pertumbuhan ekonomi yang cepat dalam kesempatan kerja, pendapatan, taraf hidup dan mengaktifkan sektor produksi lain di dalam negara penerima wisatawan (Wahab, 2003).

Dalam pembangunan pariwisata, desa selalu menempati posisi yang penting dan strategis untuk dikembangkan. Selain daya tarik khas yang semakin diminati oleh wisatawan, pengembangan pariwisata desa berarti memberikan manfaat yang nyata bagi perbaikan kehidupan masyarakat dari aspek ekonomi dan pendapatan. WTO (1996) dalam Seryasat et al., (2013) menyatakan bahwa keberadaan desa wisata dapat meningkatkan perekonomian desa untuk terus berinovasi dan berkembang melalui daya tarik wisata yang dimiliki daerah.

Menurut Muliawan (2008), pengembangan desa wisata adalah sebagai salah satu produk wisata alternatif yang dapat memberikan dorongan bagi pembangunan pedesaan yang berkelanjutan. Pigram (1993) dalam Raharjana (2005) mengatakan bahwa pengembangan desa wisata merupakan suatu bentuk pengembangan wilayah desa yang lebih cenderung pada penggalian potensi desa dengan memanfaatkan unsur-unsur yang ada dalam desa sebagai atribut produk wisata.

Pendekatan yang menempatkan masyarakat sebagai bagian yang tidak terpisahkan dari produk wisata dan pemahaman bahwa produk wisata merupakan proses rekayasa sosial masyarakat merupakan esensi dari pembangunan berbasis 
pada komunitas (Community Based Development). Arah lebih jauhnya adalah terwujudnya pemberdayaan ekonomi masyarakat desa melalui berbagai aktivitas ekonomi yang berkembang untuk menunjang potensi wisata yang dimiliki. (Suwarjo, 2019).

Salah satu desa wisata di Kabupaten Sleman yang cukup sukses mengembangkan potensi khas desa menjadi berbagai daya tarik wisata adalah Desa Wisata Pulesari Desa Kecamatan Turi. Desa wisata ini terbentuk tahun 2012 yang merupakan inisiatif dari masyarakat sadar wisata untuk mewujudkan desa yang nyaman dan diminati pengunjung. Dengan potensi agrowisata salak dipadu dengan keasrian desa yang masih alami menjadikan Desa Wisata Pulesari sangat menarik untuk dikunjungi. Penambahan berbagai sarana dan prasarana penunjang seperti river tracking untuk kegiatan outbond berbagai usia menambah daya tarik Desa Wisata Pulesari bagi banyak pengunjung.

Tantangan pengembangan Desa Wisata Pulesari di awal pembentukannya tidaklah ringan. Banyaknya desa wisata yang telah berkembang sebelumnya dengan kekuatan potensi wisata yang relatif sama di Kabupaten Sleman bagian utara maupun desa wisata di luar Kabupaten Sleman, memaksa masyarakat Desa Wisata Pulesari untuk merancang dan menyusun strategi yang berbeda dalam pengembangan berbagai potensi yang dimiliki tersebut.

Dengan kekuatan potensi wisata yang dimiliki Desa Wisata Pulesari berupa kondisi alam dan tradisi budaya yang dikelola dengan baik, pada tahun 2018 lalu dinobatkan sebagai Desa Wisata Terbaik Kabupaten Sleman tahun 2018 dalam Festival Desa Wisata 2018. Dari 31 desa wisata yang ada di Kabupaten Sleman hanya 24 Desa wisata yang berhak ikut dalam seleksi tahap selanjutnya. Penilaian berlangsung selama 1 (satu) bulan mulai 11 Oktober hingga 10 November 2018.

Di tengah tantangan dan ancaman yang semakin berat dari kompetitor pelaku Desa Wisata lainnya, pengurus dan masyarakat Desa Wisata Pulesari harus terus melakukan analisis SWOT yang meliputi Strengh (Kekuatan), Weakness (Kelemahan), Opportunity (peluang) dan Threats (Ancaman). Menurut Rangkuti (2014) analisa SWOT menggambarkan situasi dan kondisi yang sedang dihadapi dan mampu memberikan solusi untuk permasalahan yang sedang dihadapi.

Strategi pengembangan Desa Wisata Pulesari berbasis SWOT dapat digambarkan dalam kerangka pemikiran penelitian berikut ini : 


\section{Gambar 1. Kerangka Pemikiran Penelitian}

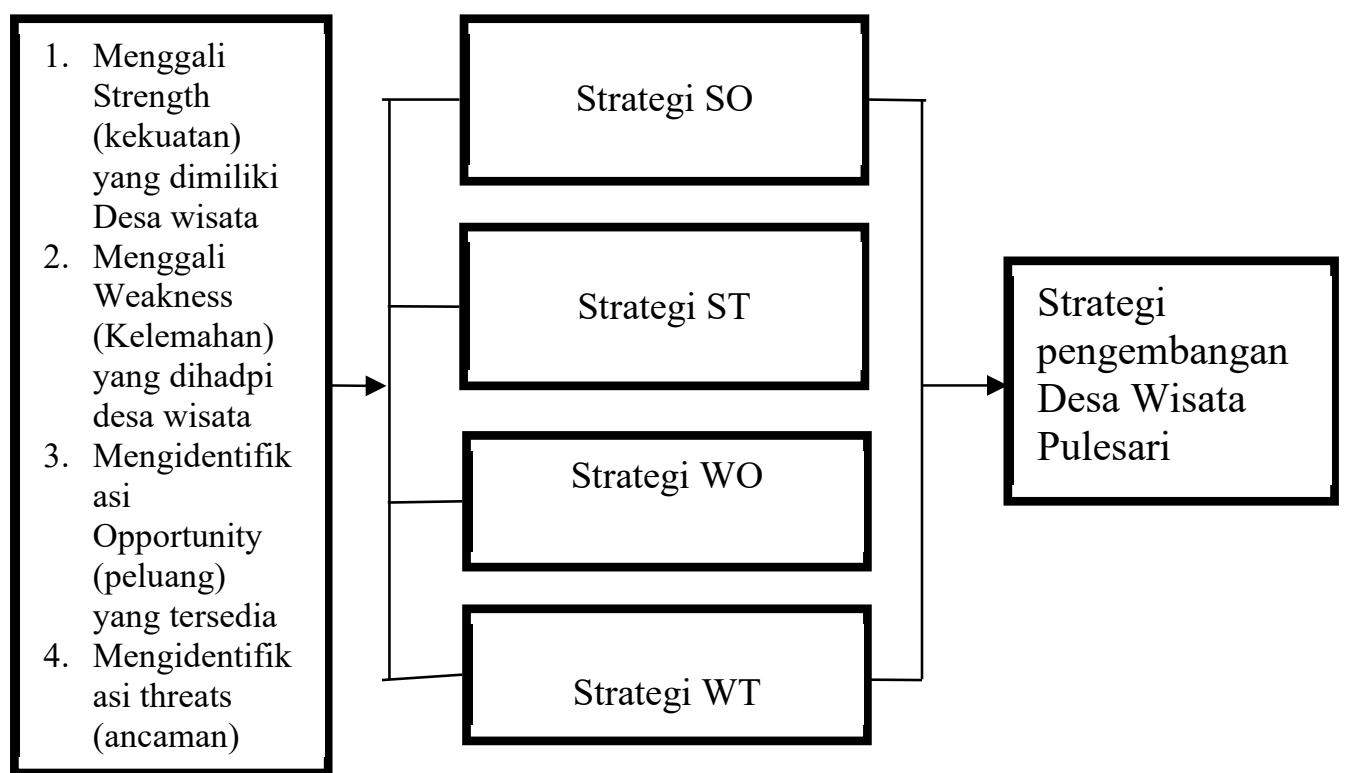

\section{Metode}

Penelitian ini merupakan penelitian deskriptif kualitatif. Pendekatan deskriptif kualitatif dianggap sesuai dengan tujuan penelitian untuk memaparkan dan mengkaji analisis SWOT dalam pengembangan Desa Wisata Pulesari Kecamatan Turi Kabupaten Sleman.

Penggalian data primer dilakukan melalui indepth interview, FGD terbatas dan pengamatan langsung serta dokumentasi. Sedangkan sumber data sekunder yaitu data yang diperoleh secara tidak langsung dari obyeknya, tetapi melalui sumber-sumber lain secara lisan maupun tulisan. Informan yang dipilih dalam penelitian ini adalah pihak-pihak yang dianggap tahu dan memahami persoalan yang diteliti diantaranya: 1) Pengurus Desa Wisata Pulesari; 2) Dukuh Pulesari; 3) Masyarakat; dan 4) instansi terkait

Data-data kualitatif yang telah terkumpul kemudian dianalisis dengan menggunakan pendekatan analisis data kualitatif. Data-data yang telah terkumpul dipilah-pilah sesuai dengan topik pembahasan yang akan diuraikan.

\section{Hasil dan Pembahasan}

\section{A. Profil Desa Wisata Pulesari}

Dusun Pulesari secara administratif berada di wilayah Desa Wonokerto Kecamatan Turi Kabupaten Sleman, Daerah Istimewa Yogyakarta (DIY). Dusun Pulesari terletak pada ketinggian 400 s/d 900 dari permukaan air laut. Dengan ketinggian tersebut, suhu udara di Dusun Pulesari relatif dingin. Dusun Pulesari merupakan daerah yang didominasi daerah pertanian dan perkebunan dengan didukung 26 sumber mata air yang mengalir pada beberapa sungai seperti Sungai Krasak dan Sungai Sempor. Dusun Pulesari memiliki luas wilayah 20,5 Ha dengan berbagai penggunaan. Penggunaan lahan terbanyak untuk perkebunan dan permukiman. 
Penduduk Dusun Pulesari terdiri dari 72 Kepala Keluarga (KK). Jumlah total penduduk sebanyak 222 jiwa yang terdiri dari 117 penduduk laki-laki dan 105 penduduk perempuan.Dusun Pulesari terbagi menjadi 2 Rukun Tetangga (RT) dan 1 Rukun Warga (RW). (Profil Dusun Pulesari, 2020)

Kekhasan Desa Wisata Pulesari adalah sajian wisata alam dan budaya tradisinya yang menarik. Potensi alam perdesaan yang asri dan perkebunan salak yang ada di hampir setiap lahan penduduk menjadi daya tarik utama selain budaya tradisional perdesaan yang menjadi daya tarik tambahan. Untuk menunjang eksistensi Desa Wisata Pulesari telah dirumuskan visi dan misi. Adapun visi Desa Wisata Pulesari adalah "Menciptakan sebuah wujud Desa Wisata Pulesari yang bersih, aman, nyaman, tentram, dinamis serta seni dan berbudaya religius yang berkualitas untuk menjadikan Desa Wisata Edukasi masyarakat tradisional". Sedangkan misi yang ingin dicapai adalah : 1) Meningkatkan kesejahteraan masyarakat dengan motivasi dan komitmen bersama membangun pola pikir yang rasional; 2) Melestarikan dan mengembangkan seni dan budaya tradisi masyarakat tradisional; 3) Meningkatkan Sumber Daya Manusia (SDM) dan Sumber Daya Alam (SDA) yang berkualitas dan berkembang; 4) Mengutamakan kualitas Desa Wisata dibandingkan kuantitas; 5) Meningkatkan kesadaran masyarakat dalam membangun Desa Wisata yang bersih, aman dan nyaman.

Kegiatan Desa Wisata Pulesari digerakkan oleh kepengurusan desa wisata yang dibentuk dalam forum warga Dusun Pulesari. Kepengurusan desa wisata diberikan tugas dan tanggungjawab dalam perencanaan kegiatan-kegiatan, membangun jaringan sekaligus mengelola pembagian tugas dalam pelayanan tamu wisata. Berikut ini susunan pengurus Desa Wisata Pulesari :

Gambar 2. Struktur Kepengurusan Desa Wisata Pulesari

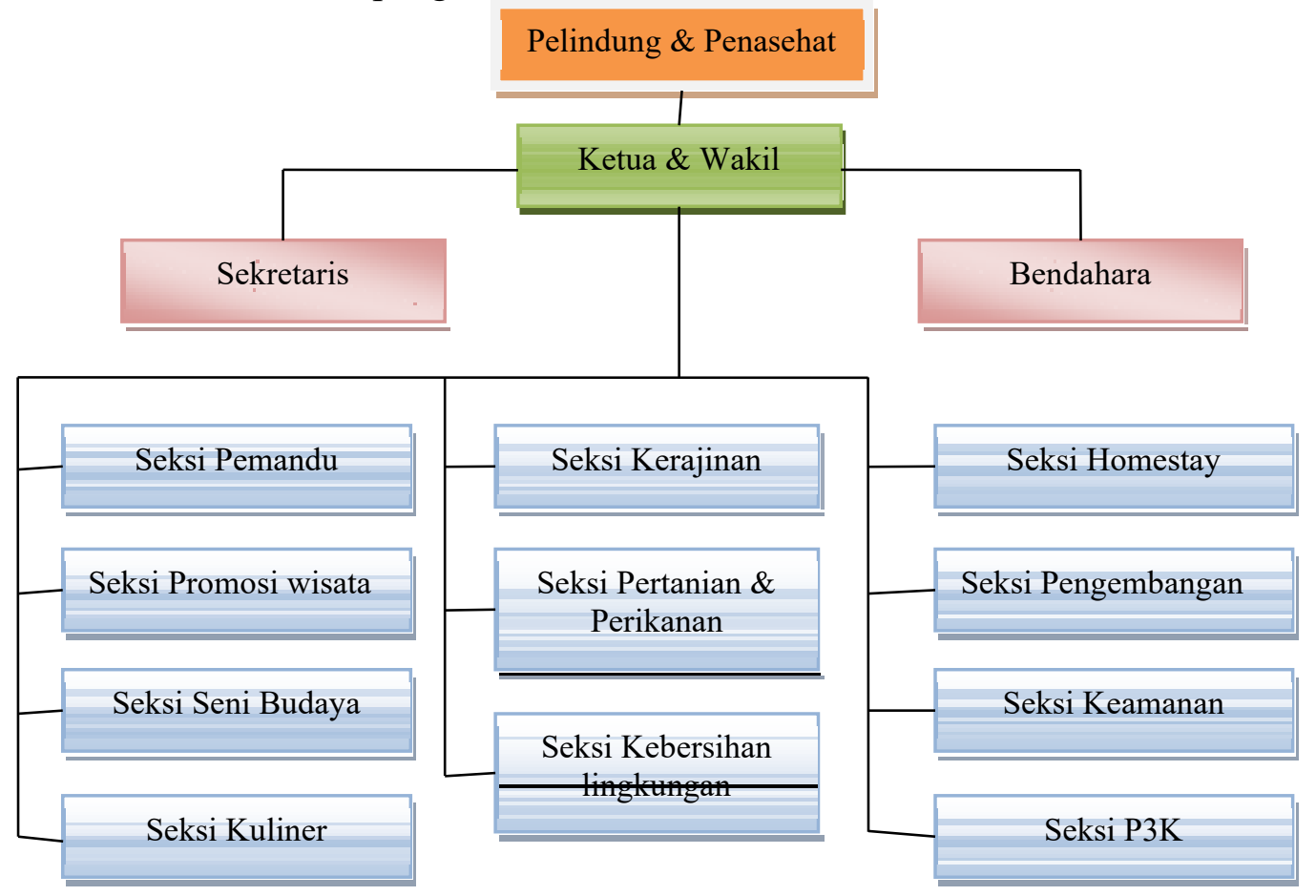




\section{B. Analisis SWOT dalam Pengembangan Desa Wisata Pulesari}

Ide dan gagasan pengembangan Dusun Pulesari menjadi Desa Wisata barangkali tidak akan pernah muncul jika tidak terjadi erupsi Gunung Merapi pada Oktober 2010, satu dekade yang lalu. Bermula dari dampak erupsi Gunung Merapi tahun 2010 tersebut ternyata menggugah warga Dusun Pulesari untuk bangkit dengan gagasan baru yaitu mewujudkan desa wisata.

Bencana membawa berkah, begitu yang dirasakan dan dibuktikan oleh masyarakat Dusun Pulesari. Lahirnya gagasan pembentukan desa wisata di Dusun Pulesari ternyata muncul di pasca musibah erupsi Gunung Merapi. Di saat erupsi Gunung Merapi, semua warga Dusun Pulesari mengungsi dari tempat tinggalnya. Sebagian mengungsi di beberapa barak pengungsian yang disediakan pemerintah, sebagian lainnya mengungsi di tempat kerabat mereka. Pasca erupsi dan diperbolehkannya warga masyarakat kembali di dusunnya, mereka mendapati kondisi rumah dan kebun salak dalam kondisi rusak parah dan sebagiannya hancur. Bahkan sebagian kebun salak tidak dapat diselamatkan karena kerusakannya sudah sangat parah. Padahal kebun salak merupakan sumber mata pencaharian sebagian besar warga Dusun Pulesari sebelumnya.

Digulirkannya program padat karya pasca erupsi Gunung Merapi oleh Pemerintah Kabupaten Sleman untuk membenahi rumah dan lingkungan dusun yang rusak akibat hujan abu dan pasir dirasakan sangat membantu masyarakat dari sisi pendapatan. Minimal masyarakat memiliki sumber pendapatan dengan adanya program padat karya meski tidak permanen. Mereka sadar bahwa program padat karya tersebut tidak akan terus dilakukan sehingga warga masyarakat mulai membersihkan kebun salak yang rusak dan berupaya agar pohon-pohon salak tetap bisa hidup meski perlu waktu yang cukup lama untuk bisa berproduksi kembali.

Di tengah ketidakpastian sumber mata pencaharian pasca program padat karya, ada beberapa tokoh masyarakat yang melontarkan ide gagasan menjadikan Dusun Pulesari menjadi desa wisata. Atas gagasan tersebut, banyak masyarakat yang pesimis meski ada beberapa yang mulai menaruh harapan setelah disampaikan tentang kisah sukses beberapa dusun lain di wilayah Kabupaten Sleman yang telah mewujudkan desa wisata.

Berbekal keyakinan dan semangat untuk bangkit dari keterpurukan akibat erupsi Gunung Merapi 2010, masyarakat Dusun Pulesari memulai langkah nyata untuk mewujudkan Dusun Pulesari menjadi desa wisata. Langkah awal yang dilakukan adalah bergotong royong untuk membenahi dan memperbaiki tampilan wajah dusun, memperbaiki rumah yang rusak, membenahi kebun salak yang rusak, membersihkan jalan dari kerikil dan pasir.

Semangat yang kuat dari segenap warga Dusun Pulesari untuk mewujudkan desa wisata juga diikuti dengan upaya belajar dari pengalaman desa wisata lain dalam pengelolaan desa wisata ataupun mendatangkan narasumber yang dianggap memiliki kemampuan untuk memberikan masukan dan saran dalam pengembangan potensi lokal menjadi daya tarik wisata. Masukan dan saran untuk mewujudkan desa wisata yang diterima dan sekiranya mampu dikerjakan, segera mungkin ditindaklanjuti dengan aktivitas gotong royong dan swadaya masyarakat. Akhirnya 
pada tanggal 10 Oktober 2012, Dusun Pulesari secara resmi dilounching oleh Dinas Kebudayaan dan Pariwisata Kabupaten Sleman menjadi Desa Wisata Pulesari.

\section{Matriks Analisis SWOT Desa Wisata Pulesari}

Pengembangan desa wisata menjadi destinasi wisata yang diminati bukan upaya yang mudah dan tanpa kendala serta tantangan. Persaingan daya tarik di antara desa wisata yang ada di wilayah Kabupaten Sleman maupun di wilayah D.I. Yogyakarta adalah tantangan yang akan terus dihadapi Desa Wisata Pulesari ke depan. Konsekuensinya, upaya peningkatan daya tarik wisata di Desa Wisata Pulesari harus terus diupayakan melalui upaya identifikasi kekuatan, kelemahan, peluang dan ancaman yang dikenal dengan istilah SWOT (Strength, Weakness, Opportunity, Threats).

Identifikasi SWOT Desa Wisata Pulesari meliputi beberapa aspek yaitu aspek lingkungan alam, ekonomi, sosial budaya, dan dukungan masyarakat dan pemerintah. Berikut tabel matriks SWOT Desa Wisata Pulesari :

Tabel 1. Matriks Faktor Internal

\begin{tabular}{|c|c|c|}
\hline Aspek & Strength & Weakness \\
\hline Ekonomi & $\begin{array}{l}\text { Penghasil komoditas salak } \\
\text { pondoh. Luas lahan perkebunan } \\
\text { salak } 8,05 \text { Ha dari total luas Dusun } \\
\text { Pulesari 20,5 Ha } \\
\text { Memiliki angkatan kerja muda } \\
\text { yang cukup banyak } \\
\text { Memiliki potensi untuk } \\
\text { dikembangkan menjadi desa } \\
\text { wisata yang sedang berkembang di } \\
\text { banyak daerah }\end{array}$ & $\begin{array}{l}\text { Belum ada kreatifitas mengolah } \\
\text { salak menjadi produk olahan } \\
\text { lain yang lebih bernilai ekonomi } \\
\text { Sebagian masyarakat bekerja di } \\
\text { perkebunan salak atau sawah } \\
\text { dengan penghasilan yang relatif } \\
\text { rendah } \\
\text { Angkatan kerja muda cenderung } \\
\text { memilih bekerja keluar dusun }\end{array}$ \\
\hline $\begin{array}{l}\text { Lingkungan } \\
\text { alam }\end{array}$ & $\begin{array}{l}\text { Suasana dusun yang asri dan } \\
\text { sejuk. } \\
\text { Memiliki beberapa sumber mata } \\
\text { air yang jernih yang mengalir } \\
\text { melalui } 2 \text { sungai dangkal yang } \\
\text { mengapit Dusun Pulesari }\end{array}$ & $\begin{array}{l}\text { Beberapa ruas jalan menuju } \\
\text { dusun rusak dan berlubang } \\
\text { Pemanfaatan sumber mata air } \\
\text { yang mengalir ke sungai masih } \\
\text { sebatas untuk pengairan kebun } \\
\text { salak dan sawah }\end{array}$ \\
\hline $\begin{array}{l}\text { Sosial } \\
\text { budaya }\end{array}$ & $\begin{array}{l}\text { Memiliki tradisi gotong royong } \\
\text { yang kuat } \\
\text { Memiliki tradisi-tradisi lokal yang } \\
\text { unik seperti upacara adat pager } \\
\text { bumi “sapar rebo pungkasan”, } \\
\text { nyadran } \\
\text { Memiliki museum salak Dewi } \\
\text { Pule } \\
\text { Terdapat rumah-rumah tradisional } \\
\text { seperti pendopo joglo dan limasan } \\
\text { Penduduk yang ramah }\end{array}$ & $\begin{array}{l}\text { Masih terbatasnya pendidikan } \\
\text { dan pengetahuan sebagian } \\
\text { warga masyarakat } \\
\text { Masih terbatasnya jaringan } \\
\text { hubungan dengan pihak luar } \\
\text { Pengelolaan museum salak } \\
\text { Dewi Pule belum optimal }\end{array}$ \\
\hline
\end{tabular}




\begin{tabular}{lll}
\hline $\begin{array}{l}\text { Dukungan } \\
\text { masyarakat }\end{array}$ & $\begin{array}{l}\text { Masyarakat memiliki keinginan } \\
\text { untuk mengembangkan wisata }\end{array}$ & $\begin{array}{l}\text { Koordinasi antar berbagai pihak } \\
\text { belum optimal }\end{array}$ \\
$\begin{array}{l}\text { desa } \\
\text { pemerintah }\end{array}$ & $\begin{array}{l}\text { Pemerintah desa mendukung } \\
\text { pengembangan desa wisata }\end{array}$ \\
\hline
\end{tabular}

(Sumber : analisis peneliti, 2020)

Tabel 2. Matriks Faktor Eksternal

\begin{tabular}{|c|c|c|}
\hline Aspek & Opportunity & Threat \\
\hline \multirow[t]{4}{*}{ Ekonomi } & $\begin{array}{l}\text { Berkembangnya trend wisata ke } \\
\text { desa dengan keasrian alam } \\
\text { pedesaan yang masih alamiah }\end{array}$ & \multirow{4}{*}{$\begin{array}{l}\text { Banyak desa wisata yang telah } \\
\text { eksis maupun yang sedang } \\
\text { dalam perintisan yang memiliki } \\
\text { keunggulan daya tarik yang } \\
\text { relatif sama dan bersaing }\end{array}$} \\
\hline & $\begin{array}{l}\text { Trend minat berwisata yang } \\
\text { semakin meningkat di kalangan } \\
\text { masyarakat }\end{array}$ & \\
\hline & $\begin{array}{l}\text { Meningkatnya minat masyarakat } \\
\text { terhadap destinasi wisata baru } \\
\text { yang menawarkan daya tarik } \\
\text { berbeda dengan destinasi lain }\end{array}$ & \\
\hline & $\begin{array}{l}\text { Teknologi informasi yang } \\
\text { berkembang cepat yang dapat } \\
\text { dimanfaatkan untuk promosi }\end{array}$ & \\
\hline $\begin{array}{l}\text { Lingkungan } \\
\text { alam }\end{array}$ & $\begin{array}{l}\text { Memiliki lingkungan alam yang } \\
\text { bisa dikembangkan menjadi daya } \\
\text { tarik wisatawan jika diolah dengan } \\
\text { baik }\end{array}$ & $\begin{array}{l}\text { Jarak yang relatif dekat dengan } \\
\text { puncak Gunung Merapi yang } \\
\text { sewaktu-waktu bisa erupsi }\end{array}$ \\
\hline $\begin{array}{l}\text { Sosial } \\
\text { budaya }\end{array}$ & $\begin{array}{l}\text { Ada dorongan kuat masyarakat } \\
\text { untuk mengembangkan destinasi } \\
\text { wisata desa }\end{array}$ & $\begin{array}{l}\text { Akses ke wilayah kota yang } \\
\text { relatif dekat berpotensi } \\
\text { menyebabkan perubahan ikatan } \\
\text { sosial budaya masyarakat }\end{array}$ \\
\hline \multirow{2}{*}{$\begin{array}{l}\text { Dukungan } \\
\text { masyarakat } \\
\& \\
\text { pemerintah }\end{array}$} & \multirow{2}{*}{$\begin{array}{l}\text { Adanya dukungan dari pemerintah } \\
\text { Desa hingga Dinas terkait untuk } \\
\text { pengembangan desa wisata }\end{array}$} & $\begin{array}{l}\text { Pengetahuan tentang wisata } \\
\text { secara umum belum dipahami }\end{array}$ \\
\hline & & $\begin{array}{l}\text { Masih kurangnya pendampingan } \\
\text { secara intens dari pemerintah } \\
\text { dalam pengembangan wisata } \\
\text { desa }\end{array}$ \\
\hline
\end{tabular}

(Sumber : analisis peneliti, 2020)

Identifikasi faktor internal (kekuatan dan kelemahan) dan faktor eksternal (peluang dan ancaman) yang menjadi dasar penyusunan matriks SWOT tersebut merupakan hasil analisa peneliti setelah melihat kondisi sosial, ekonomi, budaya dan lingkungan alam di Dusun Pulesari. Analisa SWOT sebagai dasar pengembangan desa wisata sangat diperlukan agar memudahkan merumuskan strategi dan program yang akan dilaksanakan. Tahapan-tahapan strategi dan program diperlukan agar tujuan-tujuan dapat dicapai sesuai harapan. Tentunya pada 
awal pembentukan Desa Wisata Pulesari, analisa SWOT secara mendalam belum dilakukan karena keterbatasan pengetahuan masyarakat.

\section{Analisa Strategi dan program Pengembangan Desa Wisata Pulesari}

Strategi pengembangan Desa Wisata Pulesari dapat diambil berdasarkan matriks analisis SWOT sebagaimana telah dipaparkan sebelumnya. Strategi yang dikembangkan meliputi competitive strategies, diversification strategies, overview strategies dan defensive strategies. Berikut ini uraian dari masing-masing strategi yang dapat dikembangkan :

\section{a. Competitive Strategies (SO)}

Competitive strategies merupakan strategi yang bersifat kompetitif dengan memanfaatkan peluang yang ada dengan kekuatan yang dimiliki. Beberapa strategi yang dapat dikembangkan diantaranya :

1) Mengidentifikasi dan memilih potensi lokal yang dinilai memiliki daya tarik tinggi.

Dusun Pulesari memiliki beberapa potensi yang dapat dikembangkan menjadi daya tarik wisata diantaranya suasana desa yang asri dan sejuk, kebun salak pondoh yang luas di sekeliling rumah tempat tinggal penduduk dan memiliki beberapa mata air dengan aliran sungai yang jernih dan dangkal. Potensi alam tersebut adalah daya tarik yang sejak awal dikembangkan. Namun demikian, diperlukan penonjolan pada potensi lokal yang menjadi unggulan wisata desa di Dusun Pulesari. Peneliti melihat potensi lokal berupa sumber mata air dan aliran sungai yang jernih dan dangkal dapat dikembangkan lebih baik lagi menjadi lokasi outbond permainan air atau jelajah sungai (river tracking). Menambah kelengkapan sarana outbond permainan air diperlukan meskipun dengan bahanbahan yang sederhana. Dari pengamatan peneliti, tamu wisata yang berkunjung ke Desa Wisata Pulesari sangat menyukai outbond permainan air dan jelajah sungai.

2) Menambah rumah tradisional joglo sebagai tempat pertemuan kunjungan tamu rombongan

Trend kunjungan tamu rombongan yang terus meningkat, memerlukan tempat pertemuan yang memadai. Strategi yang telah dilakukan adalah menyediakan rumah joglo untuk pusat kegiatan tamu rombongan sebanyak 9 (sembilan) buah. Sebanyak 8 (delapan) dari 9 (sembilan) rumah joglo disediakan oleh warga masyarakat, sedang 1 (satu) rumah joglo merupakan hasil swadaya masyarakat. Setiap rumah Joglo memiliki halaman namun luasannya berbeda-beda tergantung ketersediaan tanah dari pemilik rumah joglo tersebut. Kondisi tersebut menjadi masalah ketika jumlah rombongan tamu dalam jumlah banyak berkunjung dalam waktu yang bersamaan, pembagian rumah joglo sedikit mengalami kerepotan.

3) Penyajian kegiatan tradisi lokal sebagai daya tarik wisata

Dusun Pulesari memiliki tradisi dan budaya lokal yang menarik seperti rumah pendopo Joglo dan tradisi budaya lokal berupa upacara adat Pager Bumi "Sedekah Sapar Rebo Wekasan" yang diselenggarakan tiap tahun. Selain itu juga memiliki kesenian lokal lainnya seperti kesenian Kubro Siswo, Tari Salak, 
Jathilan dan karawitan. Kegiatan tradisi budaya dan kesenian lokal tersebut dapat dikemas dengan baik dan menarik sehingga menjadi daya tarik tambahan Desa Wisata Pulesari.

4) Penyediaan homestay yang memenuhi standar kenyamanan sebagai daya tarik wisata

Kunjungan wisatawan yang terus meningkat ke Desa Wisata Pulesari memberikan peluang penyediaan layanan homestay. Saat ini beberapa homestay untuk tamu rombongan telah ada dan disediakan oleh penduduk setempat. Namun belum semua homestay memiliki standar fasilitas yang sama karena kemampuan masing-masing penduduk yang berbeda. Di tengah semakin banyaknya kunjungan wisata, strategi penyediaan homestay dengan standar fasilitas yang lebih memadai sangat diperlukan.

5) Meningkatkan daya tarik Museum Salak Dewi Pule dengan penambahan koleksi Minat kunjungan tamu ke Museum Salak Dewi Pule hingga saat ini masih rendah. Koleksi museum yang masih terbatas dan tidak memiliki keunikan khusus. Koleksi yang ada di museum tersebut saat ini berupa alat-alat pertanian yang digunakan untuk mengolah tanah hingga peralatan pemeliharaan pohon salak seperti pacul, sabit dan sejenisnya. Koleksi peralatan pertanian tersebut adalah peralatan yang umum digunakan petani di manapun tempatnya. Penambahan koleksi yang unik dan tidak terbatas pada peralatan pertanian salak diperlukan untuk mendongkrak daya tarik berkunjung ke museum.

\section{b. Diversification Strategies (ST)}

Strategi diversifikasi merupakan strategi mengoptimalkan kekuatan yang dimiliki sehingga dapat meminimlisir ancaman yang ada. Beberapa strategi yang dapat dilakukan adalah :

1) Mengembangkan ikon khas wisata yang berbeda dengan desa wisata lain di wilayah Sleman

Kekhasan daya tarik wisata desa wisata sangat diperlukan agar memiliki ciri khas yang berbeda dengan desa wisata lainnya.Sejak awal dikembangkan menjadi desa wisata, Dusun Pulesari cenderung memilih ikon khas wisata desa dengan suasana alam yang asri plus outbond air dan river tracking sebagai daya tarik unggulan. Ikon khas tersebut perlu untuk disematkan dalam berbagai promosi baik melalui website maupun pengenalan kepada tamu yang berkunjung ke Desa Wisata Pulesari.

Untuk mendukung ikon khas tersebut diperlukan pemandu wisata dan pemandu outbond yang memiliki kapasitas yang dibutuhkan. Pelibatan masyarakat dalam kegiatan tersebut dapat dilakukan dengan terlebih dahulu memberikan pelatihan khusus sebagai pemandu wisata maupun instruktur outbond.

2) Memupuk terus keramahan, semangat kebersamaan dan gotong royong Keramahan, semangat kebersamaan dan gotong royong adalah nilai-nilai yang sangat penting bahkan nilai-nilai itulah yang selama ini menjadi kunci suksesnya pengembangan Desa Wisata Pulesari. Nilai-nilai tersebut sangat membantu dalam pengembangan desa wisata ditengah kemajuan teknologi informasi yang dipenuhi budaya-budaya negatif yang dapat mengikis nilai-nilai luhur tradisional tersebut. 
3) Peningkatan kapasitas pengelola desa wisata dan masyarakat yang terlibat dalam layanan wisata

Seiring dengan perkembangan di dunia kepariwisataan dan tuntutan layanan wisata yang dinamis, diperlukan terus peningkatan kemampuan pengelola desa wisata dan masyarakat yang terlibat dalam layanan wisata di Desa Wisata Pulesari. Upaya tersebut dapat dilakukan dengan menjalin komunikasi dan kerjasama dengan instansi terkait maupun pihak lain untuk memberikan pelatihan-pelatihan dan sharing pengetahuan dan pengalaman dalam pengelolaan desa wisata dan eksplorasi potensi lokal yang belum dioptimalkan sebagai daya tarik wisata. Manfaat lain dari kerjasama yang dibangun dengan berbagai pihak dapat berupa alokasi anggaran untuk bantuan kegiatan-kegiatan dan penyediaan fasilitas penunjang layanan wisata dan sebagainya.

\section{c. Overview Strategies (WO)}

Strategi ini bermaksud untuk memperkecil kelemahan yang ada dengan memanfaatkan peluang eksternal yang ada. Beberapa strategi yang dapat dilakukan adalah :

1) Penyelenggaraan pelatihan pengolahan buah salak menjadi aneka makanan dan minuman, pengemasan dan pemasarannya bagi angkatan kerja muda.

Produk hasil pertanian utama Dusun Pulesari adalah buah salak yang hingga saat ini dipasarkan dalam bentuk apa adanya sehingga nilai ekonominya masih relatif rendah. Hal itu berpengaruh secara langsung pada pendapatan masyarakat yang relatif rendah juga. Akibatnya sektor perkebunan salak tidak menjadi pilihan pekerjaan yang menarik bagi angkatan kerja muda. Banyak angkatan kerja muda Dusun Pulesari lebih memilih mencari pekerjaan di luar dusun, seperti ke perkotaan Kabupaten Sleman atau di Kota Yogyakarta.

Kondisi tersebut tentunya tidak diharapkan, sehingga diperlukan strategi untuk mengolah produk pertanian salak yang merupakan hasil pertanian utama Dusun Pulesari menjadi aneka produk olahan yang lebih bernilai ekonomis. Pelatihan pengolahan buah salak menjadi berbagai makanan dan minuman diperlukan bagi generasi muda agar bisa menjadi alternatif pilihan pekerjaan di dusun sendiri. Tidak hanya pelatihan pengolahan produk salak saja namun juga perlu diberikan pelatihan tentang pengemasan dan pemasaran produk hasil olahan salak. Untuk itu, kerjasama yang dijalin dengan pemerintah pada semua tingkatan diperlukan. Demikian juga dengan pihak swasta. Bentuk kerjasama lebih mengarah pada pengajuan bantuan pelatihan pengolahan buah salak menjadi aneka produk olahan yang bernilai ekonomis dan jika memungkinkan mendapatkan jaringan dalam pemasarannya.

2) Perbaikan sarana jalan masuk Dusun

Daya tarik wisata sangat erat terkait dengan infrstruktur dan layanan wisata yang aman nyaman dan menyenangkan. Meskipun suatu obyek wisata memiliki keunggulan dari daya tariknya tetapi jika akses jalan menuju lokasi tersebut tidak memadai, akan sangat berpengaruh pada minat kunjungan wisatawan. Letak Desa Wisata Pulesari relatif tidak jauh dari perkotaan, namun akses jalan menuju lokasi tidak semuanya dalam kondisi mendukung, terutama beberapa kilometer jalan masuk, kondisinya rusak, aspal terkelupas dan relatif sempit jika kendaraan 
berpapasan. Strategi yang dapat diupayakan adalah berkoordinasi dengan pemerintah pada semua tingkatan untuk mendapatkan perhatian dan bantuan perbaikan akses jalan menuju Desa Wisata Pulesari. Dengan alasan kemajuan wisata desa di Dusun Pulesari secara tidak langsung juga akan membawa manfaat dan keuntungan bagi pemerintah daerah.

3) Membangun jejaring kerjasama dengan berbagai pihak untuk pengembangan Desa Wisata Pulesari secara berkelanjutan

Wisata identik dengan "jualan" jasa bagi semua orang. Sebagai layanan jasa, kepuasan pengguna (pengunjung) adalah nomor utama. Untuk itu tuntutan melakukan inovasi dan kreativitas dalam penyediaan layanan jasa wisata sangat diperlukan. Tidak semua fasilitas penunjang wisata yang diperlukan dapat disediakan sendiri oleh pengelola desa wisata yang bersangkutan. Perlu peran dan kontribusi dari banyak pihak untuk pengembangan wisata desa berkelanjutan. Untuk itu upaya membangun jalinan kerjasama dengan pemerintah maupun swasta harus terus dilakukan. Penyelenggaraan kegiatan yang berkolaborasi perlu diinisiasi seperti penyelenggaraan festival kesenian, festival kuliner tradisional dan lain-lain. Dengan berkembangnya teknologi informasi dan dukungan pemerintah, kegiatan-kegiatan kolaboratif yang diselenggarakan di Desa Wisata Pulesari, akan memberikan dampak semakin dikenal oleh masyarakat luas dan akan berdampak lebih lanjut pada peningkatan jumlah kunjungan wisata.

\section{d. Defensive Strategies (WT)}

Defensive strategies bertujuan untuk mengurangi kelemahan yang ada dengan upaya menghindari adanya ancaman yang terjadi. Beberapa strategi yang dapat dilakukan adalah :

1) Komersialisasi aneka produk olahan buah salak yang bernilai ekonomis

Strategi ini ditawarkan atas dasar kenyataan bahwa hampir semua penduduk Dusun Pulesari memiliki kebun salak di sekitar permukiman maupun kebun. Hasil pertanian salak sampai saat ini baru sebatas dijual dalam bentuk buah salak. Belum ada upaya mengolah buah salak menjadi makanan atau minuman yang bersifat komersial. Beberapa olahan buah salak seperti dodol salak, bakpia, wingko, enting-enting, madumongso dan beberapa makanan lain yang ditambahkan pada olahan makanan sudah dikenal oleh masyarakat namun pengolahannya hanya untuk keperluan konsumsi sendiri atau disuguhkan tamu dalam jumlah terbatas dan pelengkap sajian menu yang lain. Strategi pengembangan olahan produk salak untuk tujuan komersial perlu diupayakan melalui pelatihan-pelatihan. Potensi pasar produk olahan buah salak cukup besar di tengah minat kunjungan wisatawan yang terus meningkat di DIY. Berbagai produk olahan salak dapat menjadi oleh-oleh khas wisata bagi tamu yang berkunjung ke Desa Wisata Pulesari.

2) Menyiapkan jalur evakuasi yang aman dan cepat jika sewaktu-waktu terjadi erupsi Gunung Merapi

Letak geografis Dusun Pulesari yang tidak jauh dari puncak Gunung Merapi, menjadi ancaman sewaktu-waktu terjadi erupsi yang dampaknya berupa semburan awan panas, pasir dan kerikil dapat mencapai dusun. Sebagaimana 
yang terjadi saat Gunung Merapi mengalami erupsi bulan Oktober 2010 lalu. Erupsi Gunung Merapi dapat terjadi sewaktu-waktu sehingga proses evakuasi harus cepat dan aman. Diperlukan jalur-jalur evakuasi yang ditentukan sehingga dapat dihindarkan jatuhnya korban. Jalur evakuasi yang paling penting adalah akses jalan yang memadai baik dari sisi lebarnya maupun kondisi jalan yang tidak rusak. Proses evakuasi biasanya terjadi spontan dan bersamaan sehingga akses jalan yang memadai sangat diperlukan.

\section{Kesimpulan}

Pengembangan Desa Wisata Pulesari berbasis SWOT akan memberikan arah strategi yang tepat dan memungkinkan untuk dijalankan. Berdasarkan matriks SWOT Desa Wisata Pulesari yang telah dikaji mendalam, didapatkan beberapa strategi yang dapat diadopsi yang meliputi Competitive Strategies (SO), Diversification Strategies (ST), Overview Strategies (WO) dan Defensive Strategies (WT).

Beberapa program strategis dari Competitive Strategies (SO) adalah (1) Mengidentifikasi dan memilih potensi lokal yang dinilai memiliki daya tarik tinggi; (2) Menambah rumah tradisional joglo sebagai tempat pertemuan kunjungan tamu rombongan; (3) Penyajian kegiatan tradisi lokal sebagai daya tarik wisata; (4) Penyediaan homestay yang memenuhi standar kenyamanan sebagai daya tarik wisata; dan (5) Meningkatkan daya tarik Museum Salak Dewi Pule dengan penambahan koleksi

Diversification Strategies (ST) yang dapat diadopsi Desa Wisata Pulesari meliputi beberapa program strategis yaitu (1) Mengembangkan ikon khas wisata yang berbeda dengan desa wisata lain di wilayah Sleman; (2) Memupuk terus keramahan, semangat kebersamaan dan gotong royong; dan (3) Peningkatan kapasitas pengelola desa wisata dan masyarakat yang terlibat dalam layanan wisata.

Overview Strategies (WO) yang dapat dilakukan Desa Wisata Pulesari meliputi : (1) Penyelenggaraan pelatihan pengolahan buah salak menjadi aneka makanan dan minuman, pengemasan dan pemasarannya bagi angkatan kerja muda; (2) Perbaikan sarana jalan masuk Dusun; dan (3) Membangun jejaring kerjasama dengan berbagai pihak untuk pengembangan Desa Wisata Pulesari secara berkelanjutan

Defensive Strategies (WT) yang dapat dilakukan Desa Wisata Pulesari meliputi : (1) Komersialisasi aneka produk olahan buah salak yang bernilai ekonomis; dan (2) Menyiapkan jalur evakuasi yang aman dan cepat jika sewaktuwaktu terjadi erupsi Gunung Merapi

\section{Saran}

Dari hasil temuan penelitian tentang kajian SWOT dan analisis strategi pengembangan Desa Wisata Pulesari, maka ada beberapa rekomendasi yang disampaikan sebagai berikut :

1. Perlunya tindak lanjut pembahasan atas beberapa tawaran strategi yang telah ditawarkan di atas melalui forum di tingkat pengurus Desa Wisata Pulesari. Pembahasan tersebut diarahkan untuk menentukan skala prioritas strategi 
program yang dipilih berdasarkan kebutuhan dan kemampuan untuk mewujudkannya;

2. Perlunya Pengurus Desa Wisata Pulesari merumuskan langkah-langkah koordinasi dengan berbagai pihak : (1) Dengan Pemerintah Desa Wonokerto untuk membahas dan merumuskan pilihan strategi yang tepat untuk pengembangan Desa Wisata Pulesari sekaligus pendanaannya; (2) Dengan Pemerintah Daerah Kabupaten Sleman melalui Dinas Pariwisata Kabupaten Sleman untuk memberikan bimbingan, pelatihan, pendampingan, dan bantuan lainnya yang mendukung pengembangan Desa Wisata Pulesari; (3) pihak swasta semisal Bank dan perusahaan agar berkenan memberikan dana CSR (Cost Social Responsilibity) untuk Desa Wisata Pulesari; (4) dan pihak lain yang bisa dijalin kerjasama saling menguntungkan.

\section{Daftar Pustaka}

Muliawan, H. 2008. Pengembangan Pariwisata Berbasis Masyarakat; Konsep dan Implementasi. tanpa kota, tanpa penrbit

Raharjana, Destha Titi. 2005. Pengembangan Desa Wisata Berbasis Budaya: Kajian Etnoekologi Masyarakat Dusun Ketingan, Tirtoadi, Mlati Sleman DIY. Program Studi Ilmu Lingkungan Sekolah Pascasarjana Universitas Gadjah Mada, Yogyakarta.

Rangkuti, Freddy. 2014. Analisis SWOT; Teknik Membedah Kasus Bisnis. Gramedia: Jakarta

Seryasat, Hajari, Karimian.2013. Rural Tourism Development Strategies Using SWOT analysis: Case study. Life Science Journal $J$ 2013;10(4s):395-403] (ISSN:1097-8135)b

Suwarjo, 2019, Community Based Tourism dalam pengelolaan Desa Wisata Giriloyo, Wukirsari, Imogiri Bantul, Jurnal Populika Vol.VII No.1 Januari 2019 .

Wahab, Salah. 2003. Manajemen Kepariwisataan. Jakarta: Pradnya Paramitha 